\title{
ŽIVOT ZADRUŽNE OBITELJI: DVIJE STUDIJE SLUČAJA
}

\author{
Milana ČERNELIĆ \\ Filozofski fakultet Sveučilišta u Zagrebu \\ Odsjek za etnologiju i kulturnu antropologiju \\ Ivana Lučića 3, 10000 Zagreb
}

\section{UVOD}

$\mathrm{P}$ odaci o dvjema zadružnim obiteljima na području Krivoga Puta 1981. godine, u okviru projekta Seljačke obiteljske zadruge Odsjeka za etnologiju Filozofskog fakulteta u Zagrebu, sakupljani su u svrhu istraživanja zadružnog života na području Krivoga Puta, budući da takvih etnoloških istraživanja na ovome području ranije nije bilo. Cilj je bio, metodom studije slučaja, doznati o konkretnim primjerima zadruga $s$ ovog područja, pa je tako ovaj prilog usporedni etnografski prikaz dviju, tom prigodom istraženih zadruga s područja Krivoga Puta: Prpić-Grgajice u selu Kosovoj Buljimi i Tomljanović-Puljiz u selu Podbilu. ${ }^{1}$ Već je u to vrijeme bilo poteškoća u pronalaženju kazivača koji bi o tome mogli dati podatke, zbog čega prikupljeni podaci nisu uvijek potpuni. Osobito su manjkavi podaci o zadruzi Tomljanović-Puljiz, budući da kazivač Milan Tomljanović nije bio previše zainteresiran za razgovor, a njegova brata Franu nije bilo moguće ispitati jer je u vrijeme ispitivanja bio odsutan.

Zadruga Prpića iz Kosove Buljime nazivala se vamilija Prpić-Grgajice, dok su je sami zadrugari među sobom zvali naša vamilija. Nadimak Grgajice potječe od imena pradjeda kazivača koji se zvao Grgo. Svaka obitelj imala je svoj nadimak jer je u selu bilo čak osam obitelji Prpića, a četiri kuće bile su u bliskome srodstvu. Vamilija Prpić-Grgajice nije klasičan primjer zadruge, kao što ih već odavno u ovome kraju nema. Potomak zadruge Mirko Prpić u vrijeme ispitivanja živio je u Senju. ${ }^{2}$ Njegovo pamćenje seže do pradjeda Grge, kojega pamti samo po tome što je za 20 litara ječma kupio 20 kosaca zemlje ( 8 - 9 jutara), livada i oranica. Imao je samo jednoga sina, Grgu, jer je umro mlad, u četrdesetoj godini života. Majka mu se preudala u susjedno selo Vratarušu i po njoj ima dva brata s kojima nije živio u zajednici. Grgo je imao 4 - 5 godina kad mu je umro otac i živio je sa stricem Ilijom koji ga je odgojio u svojoj zadruzi. Ilija je živio u zajednici sa svojim bratom. Nakon ženidbe Grgo se odvojio od njih i sagradio kuću za sebe i svoju ženu. Imao je šesnaestero djece, od kojih je samo četvero ostalo na životu, dva sina, Mile i Stipe, i dvije kćeri, Kata i Mara. Ostalu djecu Mirko ne pamti jer su ubrzo nakon rođenja umrla. ${ }^{3}$ Mile, Grgin sin i otac kazivača Mirka i Jose Prpića, i njegov brat Stipe osnovali su svoju vamiliju nakon očeve smrti (Prilog 1). Dok je još Grgo bio živ, Mile je dosta putovao za zaradom. Za vrijeme Prvoga svjetskog rata, od 1914. do 1918. godine, bio je u Rusiji u zarobljeništvu. Nakon 1918. godine opet je išao na front i bio u zarobljeništvu u Italiji i Francuskoj. Zatim je od 1924. do 1925. godine, tražeći posao, putovao po Srbiji, Crnoj Gori i drugdje po Kraljevini Jugoslaviji. ${ }^{4}$ Nakon očeve smrti više nije izbivao od kuće

1 Ovaj rad već je objavljen u dva navrata i temelji se na ranije obavljenim istraživanjima (Černelić 2000; Ibid. 2006: 41-53). Budući da u vrijeme istraživanja na Krivome Putu od 2002. do 2007. više nije bilo moguće dobiti cjelovite podatke o ovome obliku obiteljskog života, uredništvo je odlučilo ovaj rad ponovno objaviti u ovoj monografiji, radi cjelovitijeg uvida u različite tipove obitelji. Prikazu obiteljskog života uopće na Krivome Putu posvećen je poseban prilog autorica Tihane Rubić i Danijele Birt i u ovom svesku Monografije. Zbog nedostatnih podataka, nije moguće rekonstruirati obiteljski život u zadrugama na čitavome ovome području, odnosno ranije prikupljene podatke upotpuniti podacima o drugim zadružnim obiteljima u ovome kraju.

2 Mirko Prpić bio je glavni kazivač, a u ispitivanju su sudjelovali još i njegova žena Ika i brat Joso.

3 Više o broju i mortalitetu djece vidi u prilogu Tihane Rubić i Danijele Birt u ovom svesku Monografije.

4 O tradiciji ekonomskih migracija vidi više u prilogu Marijete Rajković u prvom svesku Monografije, str. 79-94. 
jer je preuzeo gospodarenje u vamiliji. Stipe je kao zidar stalno putovao po Jugoslaviji, a kući je dolazio kao gost po mjesec dana. Nije slao novac u kuću jer se nije više smatran članom zadruge. Počeo je putovati vrlo mlad i nije se ženio. U zadružnoj kući imao je svoju sobu u kojoj je, kad je bio odsutan, što je i bilo najčešće, spavao njegov brat Mile sa ženom. Mirko je također već s 12 godina krenuo trbuhom za kruhom. Najprije je bio u Našicama, gdje je kuhao za brigadu 6 mjeseci. Ponovno je krenuo s 18 godina, najprije po Srbiji kao naučnik kod zidara, 1 - 2 godine, potom po Crnoj Gori, dvije godine, i po Sloveniji 4 - 5 godina. Prije nego što je postao zidar, Mirko je u Senju izučio stolarski zanat. Time se bavio u kratkim intervalima kad je boravio kod kuće. Pravio je mrtvačke škrinje i djevojačke ormare od javorovine i ljeskovine. Povremeno bi s putovanja dolazio kući na mjesec-dva. Godine 1937. došao je iz Slovenije i stavio si žrvanj za vrat (oženio se). Ponovno je otišao za Sloveniju, a zatim i u Njemačku, gdje ga je zatekao rat. Vratio se kući 1944. godine i nakon toga je, do diobe, ponovno zbog posla putovao po Srbiji i Bosni. Njegov brat Joso počeo je putovati u potrazi za poslom sa 16 godina. Bio je u Srbiji i u Njemačkoj. Do diobe je došlo 1947. godine, godinu dana prije nego se Joso oženio. Svi su zajedno živjeli u jednoj kući u dvjema sobama, dok su inače u selu u velikim vamilijama svi živjeli u jednoj sobi. ${ }^{5}$

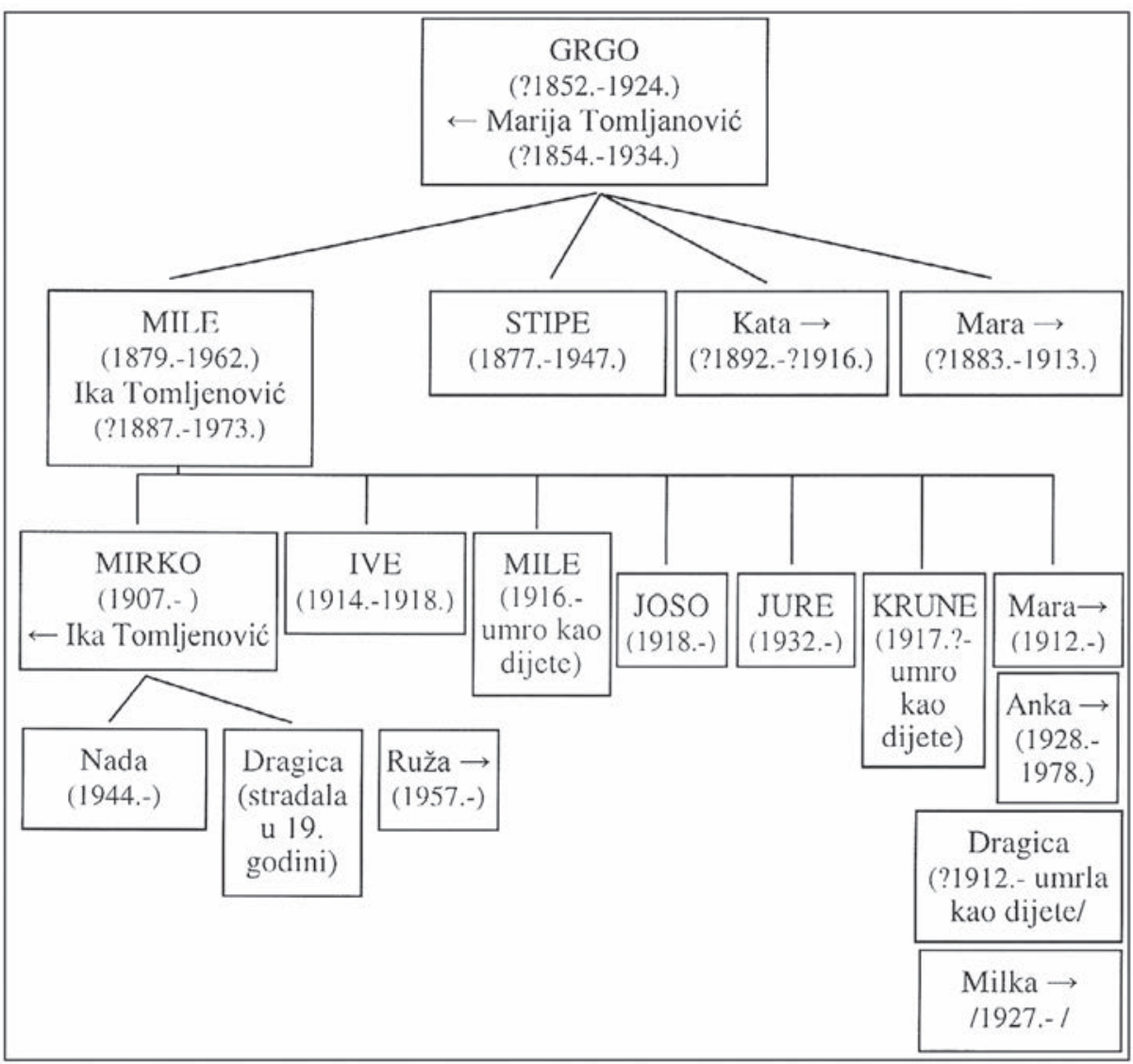

$\leftarrow$ ušla u zadrugu

$\rightarrow$ izašla iz. zadruge

Prilog 1: Rodoslovlje zadruge Prpić-Grgajice (sastavila M. Cernelić).

Budući da se zadruga sastojala samo od živućih roditelja i jednog oženjenog brata kroz dva naraštaja, ne bismo je zapravo niti mogli smatrati zadrugom u pravom značenju te riječi. Ona je i po broju članova

5 O tome više vidi u prilogu Tihane Rubić i Danijele Birt u ovom svesku Monografije. 
bila mala, no kod zadruge nije bitan broj članova, nego da se radi o načelu nepodijeljenog, odnosno, nedjeljivoga zajedničkog imutka, o zajedničkom gospodarenju, o podjednakom korištenju svih zadružnih dobara za sve članove, o poštivanju određenih pravila prigodom (načelno moguće) diobe tog imutka (Gavazzi 1978:82). Mogli bismo je označiti krnjom zadrugom, budući da nije zadovoljavala sve formalne kriterije koji jednu obitelj čine zadružnom, premda su je zadnji potomci zadruge takvom smatrali. Težak život u ovome kraju očito je zahtijevao da muški članovi obitelji putuju u potrazi za poslom, pa je tako, primjerice, Mirkov stric Stipe zbog čestog izbivanja bio oslobođen obveza prema zadruzi.

Zadruga Tomljanovića u selu Podbilu, iz zaseoka Tomići, nazivala se zadruga ili vamilija TomljanovićPuljiz(ova). ${ }^{6}$ Puljiz je nadimak obitelji, budući da je to prezime u selu vrlo često. Za obitelj Puljizovih govorilo se da su ovamo došli iz Karlobaga, ali se više ne zna kada je to bilo. Ivan Tomljanović nije živio u zadruzi sa svojom braćom budući da su se ona školovala i raselila. Živio je sam sa svojom ženom i sinovima Grgom, Milanom i Franom. Ivan je umro u 27. godini života, a sinovi Grga i Milan ostali su u zajednici s majkom i nakon ženidbe. Frano nije bio oženjen dok je trajala zadruga. Odijelili su se 1936. godine (Prilog 2). Milan se uz poljodjelstvo bavio i zidarskim i šumarskim poslovima, radio je na izgradnji cesta i tunela. Znao je izbivati po 2 - 3 mjeseca, ponekad i po 2 - 3 godine. Putovao je po Hrvatskoj i Srbiji.

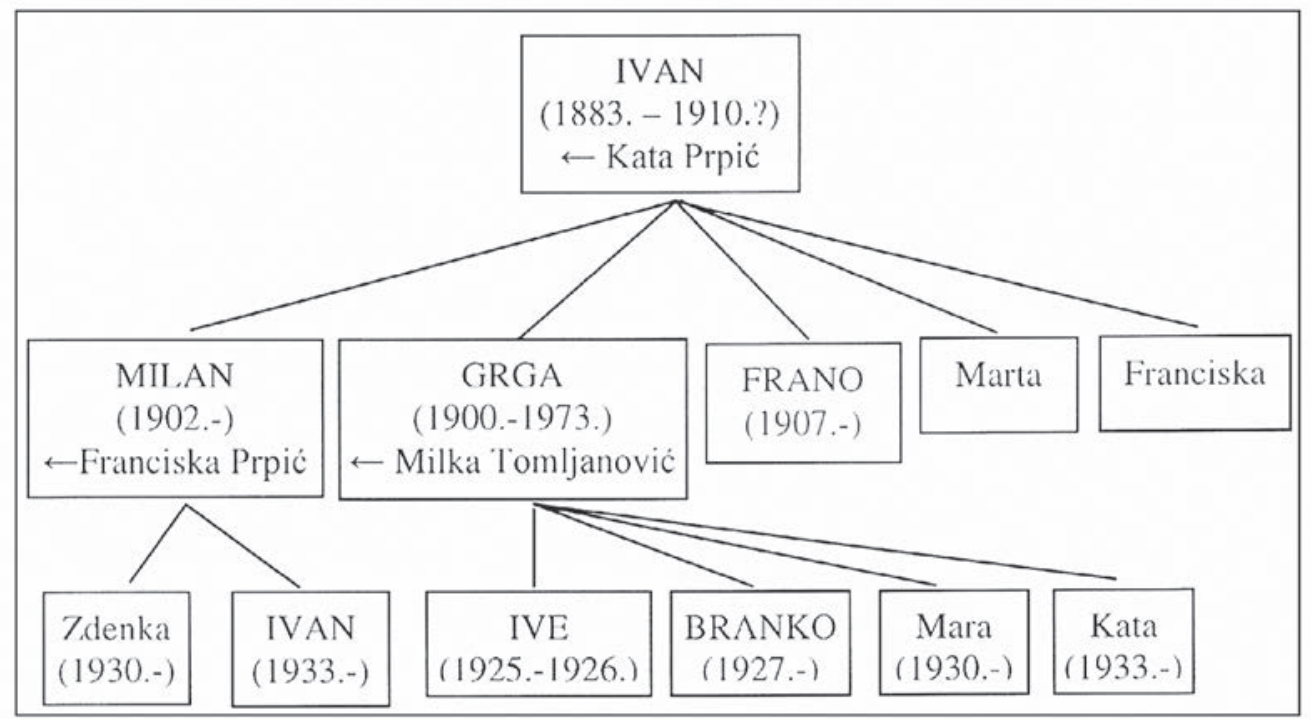

$\leftarrow$ ušla u zadrugu

$\rightarrow$ izašla iz zadruge

Prilog 2: Rodoslovlje zadruge Tomljanović-Puljiz (sastavila M. Črnelić).

\section{ZADRUŽNA IMOVINA}

$\mathrm{O}$ bje obitelji posjedovale su zemlju koju su naslijedile od svojih pradjedova, budući da se zemlja nije kupovala. Zadruga Prpić-Grgajice imala je 20 jutara zemlje. ${ }^{7}$ Najviše je bilo pašnjaka (pašanica, pašinac) i livada (košanica), oranica, nešto ledine i šume. Vode nisu imali, osim na dvama mjestima lokve s vodom zvane Liskovac i Grebenjača (Kosova Buljima), te Danilovac i Dražica (Podbilo). Nazivi pojedinih parcela livada i oranica zadruge Prpić su sljedeći: Buljik, Šimunova njiva, Latica, Prisadnjak, Buljmice,

$6 \quad$ Selo Podbilo sastoji se od 7 zaselaka: Cupići, Tomići, Panjići, Žuljevići, Marketići, Plemići, Šolići i Matići, prema iskazima kazivača.

7 Kazivač Milan Tomljanović tvrdio je da ne zna koliko je zemlje njegova zadruga posjedovala, no s obzirom na njegova suzdržana kazivanja, može se pretpostaviti da to najvjerojatnije nije želio reći. 
Zapadak, Bradva, Ograda, Livada, Jaruga, Dolac, Pleća, Poležina i dr., a zadruge Tomljanovića: Duboki dolac, Rubanuša, Greben, Šabovac, Čimarova draga, Laćevac, Křc, Ruglo, Paljevina, Draga, Zaglavica, Pekuša, Vršale, Alino bilo, Podastan, Šelimbaša, Paljenik i dr.

\section{KUĆA I KUĆIŠTE ZADRUGE PRPIĆ-GRGAJICE}

$Z^{2}$ adružna kuća Prpića u Kosovoj Buljimi bila je u vrijeme ispitivanja srušena. I nakon diobe članovi zadruge ostali su u njoj živjeti 2 - 3 godine i za to vrijeme svaka je obitelj izgradila sebi novu kuću. Rekonstrukcija kućišta napravljena je prema sjećanju Mirka Prpića (Prilog 3). Okućnica se sastojala samo od kuće i šterne (bunara). Kuća je bila zidana od kamena na kat, krov pokriven šimlom, tankim širokim daskama. Stepenicama se uspinjalo na balaturu, ulazni trijem u kuću. U gornjem se dijelu kuće u sredini nalazila kuhinja te dvije sobe sa svake strane. Inače su u selu sve velike vamilije imale samo jednu zajedničku sobu za sve članove. Cijelom dužinom sobe prema cesti prostirala se šupa, otvorena, na četiri stupa, natkrivena krovom od šimle. To je bilo spremište za kola i poljske alate. Ispod svake sobe bila je štala, a ispod kuhinje konoba, u koju se ulazilo stubama s balature. U jednom uglu kuhinje nalazio se špajz, posebna manja prostorija.

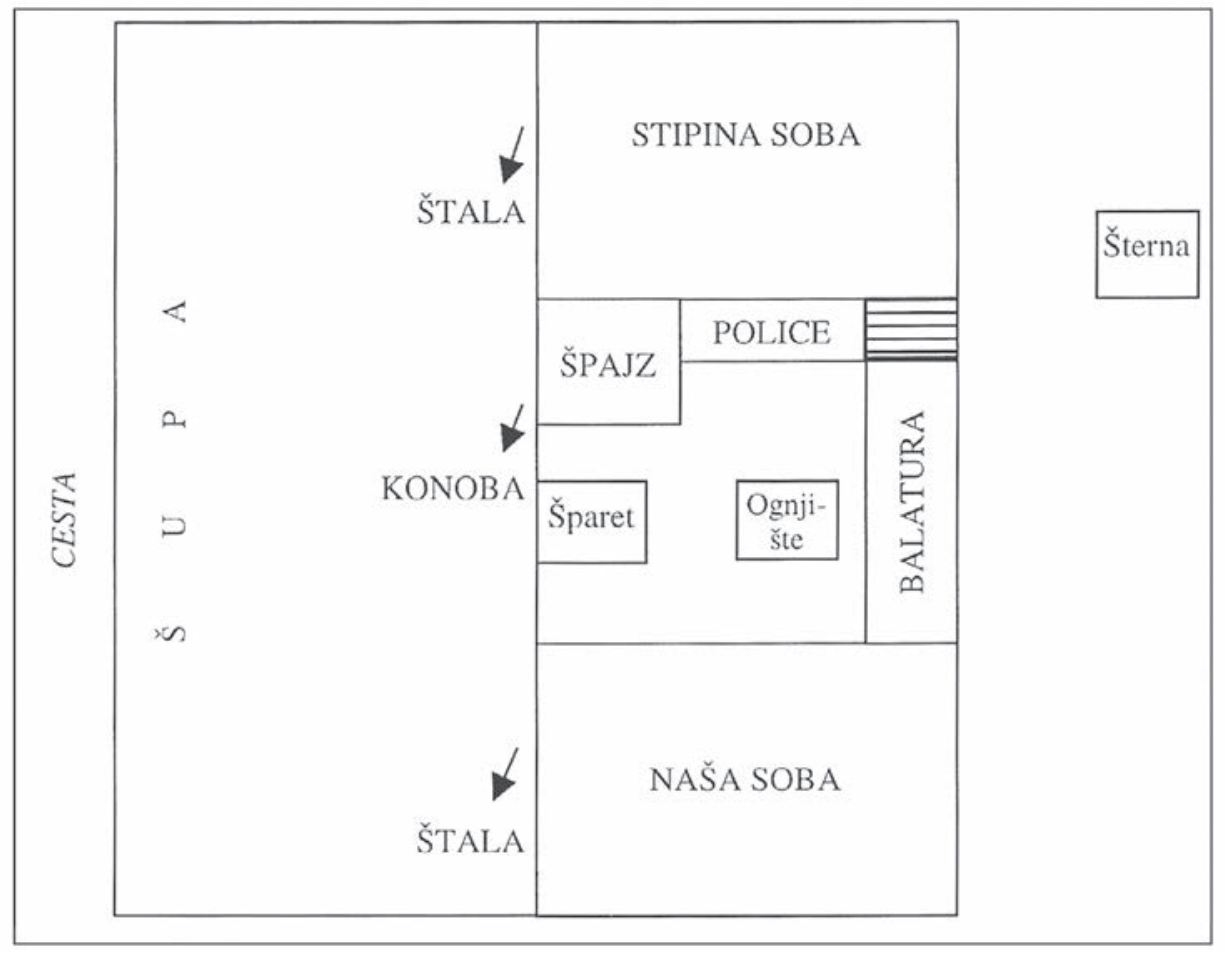

Prilog 3: Tlocrt kuće i kucísta zadruge Prpić-Grgajice (izradila M. Cernelić).

U kuhinji je do 1927. godine bilo ognjište. Sastojalo se od daske presječene na sredini gdje se stavila zemlja. Iznad ognjišta visile su komoštre na hrljiki (drvena motka). Na komoštre se objesio bakreni lonac zvan kaštrola, u kome se kuhalo. Na ognjištu su bile tronoge. Pod njih se stavljala žeravica i tako se kuhalo na samome ognjištu. Kuhinja je bila sagrađena na štuk, bez tavanice. U špajzu se držalo piće u kredencijama i sve potrepštine za kuhanje. Uz špajz su u kuhinji bile police za posuđe kao i pregrade za poklopce.

U jednoj od soba koju su zvali Stipina soba, budući da je u njoj boravio Stipe kad je povremeno dolazio kući, nalazila se visoka željezna peć i četiri kreveta. U toj je sobi inače spavao Mirko sa ženom jer je Stipe obično kratko vrijeme provodio s obitelji. Drugu sobu su zvali naša soba. Tu su spavali otac, majka i djeca. Bila su dva do tri kreveta. Djeca su spavala na podu od jelovih dasaka na biljcima. U našoj sobi je bila peć od pečenih cigala u koju se ložilo iz kuhinje. 
U konobu se stubama silazilo s balature. Tu se držalo kiselo zelje i ostalo povrće za zimu. Tu je bila i pregrada za krumpir zvana klitar. Inače se krumpir držao još i vani jer sav nije mogao stati u klitar. Iskopao bi se trap, okrugla jama u koju se stavljao krumpir, a odozgo se pokrio daskom i prekrio zemljom. Tako se krumpir čuvao preko zime do proljeća. Ispod svake sobe bile su štale s odjeljcima za ovce, krave, konje i magarce.

Na tavanu kuće držalo se sijeno i žitarice u bačvama, svaka vrsta zasebno. Hrana i kukuruz u manjim količinama su također bili pohranjeni na tavanu. Tu su se držali i plugovi ili vani na otvorenom, ovisno o vremenskim prilikama.

Pred kućom je bila šterna, iz koje se kalala (vadila) voda kalačom, limenim vedrom na lancu, koje se izvlačilo rukom. Šterna je izvana ozidana kamenom, a iznutra cimentom.

Kuća smještena uz cestu nije bila ograđena, a iza kuće bila je bašća.

\section{KUĆA I KUĆIŠTE ZADRUGE TOMLJANOVIĆ-PULJIZ}

Z adružna kuća Puljizovih sastojala se od kuhinje i sobe. Kuća je i u vrijeme ispitivanja postojala, samo što je tada već bila preuređena (sl. 1). Štala je bila zasebna prostorija i od nje je kasnije napravljena kuća za najstarijeg brata. Odmah uz kuću koja je pripala Frani, Milan je sebi izgradio novu kuću. U vrijeme ispitivanja više nije živio u selu, već u Senju. U staroj kući živjeli su Frano i njegova žena, kao jedini stalni stanovnici zaseoka Tomići u Podbilu.

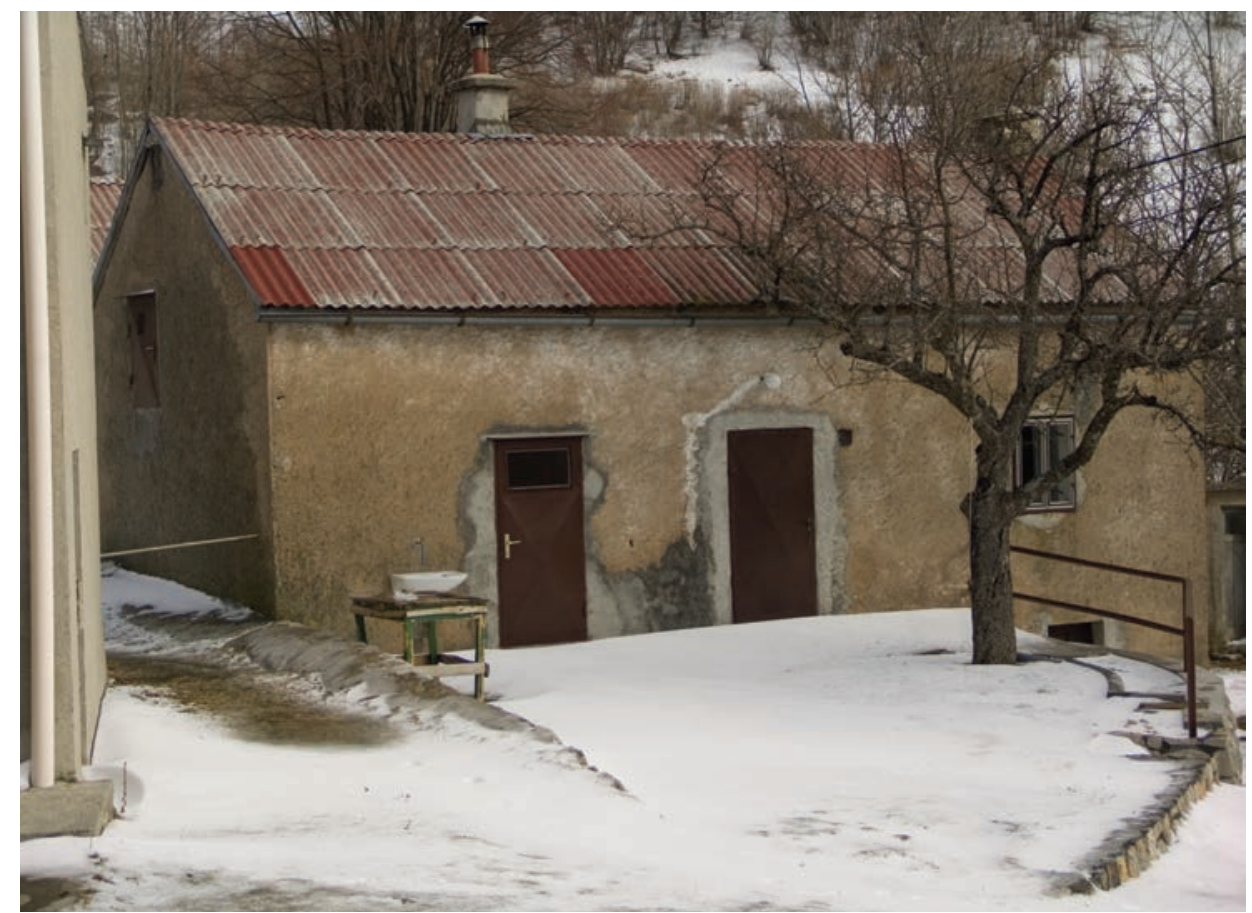

Slike 1: Stara zadrǔ̌na kuća obitelji Tomljanović-Puljiz. Snimio Augustin Perić, siječanj 2009.

Pod u kuhinji bio je zemljani, a odozgor su bile grede. Do diobe je u kuhinji bilo ognjište. Bilo je četvrtasto ozidano, s komoštrama koje su bile obješene o motku zvanu varalica. Uz ognjište je bila lopata za zgrtanje žari zvana ožak. U kuhinji je bila udubina u zidu koja je služila kao polica za posuđe. Ispod sobe u kojoj su svi zajedno spavali bila je konoba. Odmah iza kuće nalazila se štala. Sastojala se od jedne prostorije, a pojedine vrste stoke bile su jedne od drugih odijeljene pregradama. Uz štalu je bila kamena šterna s urezanom godinom izgradnje - 1863. Naziv za dvorište je prikuća. Dvorište nije bilo ograđeno (Prilog 4). Blizu kuće bilo je posađeno nešto voćaka, a u blizini je bio i vrt na parcelama Danilovac, Podvoda i Krč. 


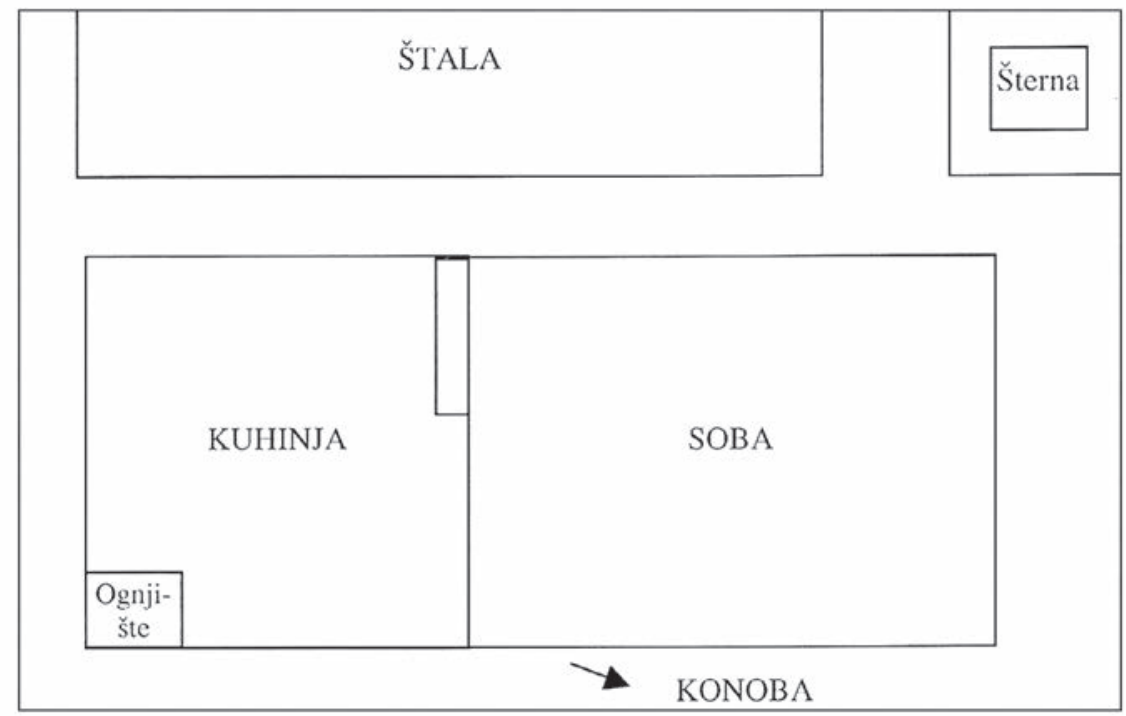

Prilog 4: Tlocrt kuće i okućnice zadruge Tomljanović-Puljiz (ižradila M. Černelić).

\section{ZAGRIJAVANJE I OSVJETLJAVANJE PROSTORIJA}

rijali su se bukovim drvima iz državne šume. Bio je određen otkaz drva (količina koja se daje za svaku

Tkuću) ${ }^{8}$

Kuća se osvjetljavala svjetiljkama na petroulje, a za štalu su se rabile zatvorene svjetiljke s ručkom zvane šišmiši. U zadruzi Prpić-Grgajice su se, kada nije bilo petroleja, upotrebljavale i uljane lampe zvane uljarice. Imale su pamučni fitilj zvan nosić. Ulje ili mast nasuli bi se u limenu posudicu te bi se potpalio pamučni fitilj. Osim toga bilo je i lučerni. Kada nije bilo ni petroleja ni masti, upalila bi se lučerna, koja se sastojala od jelove grane zvane smugor, koja je dugo svijetlila. Podaci o rasvjeti i nazivima za rasvjetna tijela u zadruzi Puljizovih donekle se razlikuju. Ako nije bilo petroleja, palila se luč. U kanticu se stavila svinjska mast i uronio pamučni kostinj koji gori. Tko je imao pčele, upotrebljavao je i svijeće od voska zvane milikerce, a ponekad i laterne od lima.

\section{ZASEBNO VLASNIŠTVO}

$\mathrm{P}$ odaci o zasebnom vlasništtvu razlikuju se u dvjema istraženim zadrugama.

U zadruzi Prpić-Grgajice zasebno vlasništvo činila je jedino próija, a to je ono što je djevojka udajom donosila u vamiliju. Obično je majka za kćer uzgojila kravu. Krava je na sebi nosila prćiju, tekstilne predmete kao što su bili biljci, plahte, prekrivači, odjeća. Krava se nastavila hraniti od zadružne hrane. Mlijeko koje je krava davala pripadalo je zajednici, dok bi tele žena prodala i raspolagala dobivenim novcem. Njime je kupovala odjeću za sebe, svojega muža i djecu. Krava je bila na zajedničku korist, a tele je pripadalo vlasniku. Próija je mogla biti i komad zemlje. Ta je zemlja postala zadružno vlasništvo, zajednički se koristila. U slučaju diobe taj bi komad zemlje pripao obitelji muža i žene, čija je to prćija bila, povrh zemlje koja se kao zajednička dijelila između obitelji.

Prema Milanu Tomljanoviću u zadruzi Puljizovih nije bilo zasebna vlasništva. Jedino je dota bila vlasništvo žene. Pod dotom se podrazumijevalo sve što je žena udajom donosila u novi dom: štramac za spavanje, biljac, prešlica. U slučaju da je žena ostala udovica i da se ponovno udala, odnosno otišla iz zadruge, svoju je dotu nosila sa sobom. Kod Puljizovih drugog oblika privatnog vlasništva nije bilo, ali je u selu bilo zadruga u koje je žena kao dio dote donijela i komad zemlje ili blago.

Za zadrugu Tomljanović-Puljiz nema podataka o zagrijavanju zadružnih prostorija. 
Tkalački stan zadruge nisu imale jer se u ovome kraju nije tkalo ni u starini, već se odjeća kupovala. Svaka žena imala je vlastitu prešlicu kao dio svoje prćije, odnosno dote.

\section{GOSPODARENJE}

$\mathrm{U}$ zadruzi Prpića držali su 5 - 6 krava, 2 - 3 svinje, po 15 ovaca i jednog magarca. Ovce su imale svoju gajbu u štali. Bio je po jedan bik za dva do tri sela. Zadruga Tomljanovića imala je 4 - 5 krava, 1 - 2 svinje, 15 - 20 ovaca i 1 - 2 konja. Obje su zadruge imale kokoši, pse i mačke.

Od oruđa su obje zadruge posjedovale drveni plug i kola. ${ }^{9}$

Blago se izgonilo na pašnjake, kako Milan Tomljanović kaže, na ispašinac. To je bio posao uglavnom predškolske djece, ali i nešto starije kada nisu bila u školi. Zimi i ujesen blago bi po cijeli dan bilo na paši, a ljeti od jutra do 10 - 11 sati (Mirko Prpić: vraćaju se kući na popas), a predvečer kada sunce popusti, ponovno se goni na pašu. ${ }^{10}$

U zadruzi Prpić-Grgajice mlijeko su trošili i prerađivali ga. Pravili su sir od teletije mirice (želuca) kao sirišta. Kada se usiri, izažima se rukama i zamota u krpu, oblikuje i stavlja na tanjur za upotrebu, a ako se ostavi za kasnije, još se i osuši. Putar se meja (inf. mesti) u stapu pomoću mećaje. Mlijeko se prodavalo. Stanovnici Krivoga Puta prodavali su mlijeko u Senju. Transportiralo se u kantelatama (limenim kantama) na magarcu, a tko ga nije imao, na leđima. Žene su rano ujutro, u 4 - 5 sati raznosile mlijeko. To je radila majka, čak i baba, uglavnom starije žene, a gdje ih je bilo, i djevojke. I u zadruzi Puljizovih pravili su se sir, kiselina i maslac, ali se mlijeko i mliječni proizvodi nisu prodavali. ${ }^{11}$

Od ovčje vune žene su plele čarape, maje i strample za potrebe članova zadruge. ${ }^{12}$ Prpići su nešto vune prodavali, za razliku od Tomljanovića. Ovčje se meso stavljalo na dim. Meso su dimili nad ognjištem. ${ }^{13}$ Obje su obitelji držale svinje samo za vlastite potrebe, da imaju dovoljno suha mesa i masti preko godine.

Lovom i ribolovom nisu se bavili. Tomljanovići se nisu bavili niti pčelarstvom, dok je u zadruzi Prpića uzgoj pčela bio važna privredna grana. Imali su 2 - 3 ulišta i 10 - 15 rojeva pčela. Pčele su držali pred kućom, a u jesen i zimu na podu (tavanu). ${ }^{14}$ Med se prodavao, a zaradom je raspolagala zajednica.

Od žitarica su uzgajali pšenicu, ječam i zob, a Tomljanovići su uzgajali još i nešto kukuruza i jeldu za svinje. Zemlja je bila pogodna za uzgoj kukuruza, ali se sijalo malo zbog jakog vjetra. Imali su vrta blizu kuće. Od povrća su sadili krumpir, grah, zelje, blitvu, kumiradu (korabu), ripu, mernu (mrkvu). ${ }^{15}$

Najveći je dio zemlje zadruge Prpić-Grgajice bio pod pašnjacima i livadama. Godišnji urod pšenice prosječno je iznosio 2 - 3 kvintala $(1 \mathrm{kvintal}=100 \mathrm{~kg}), 6$ - 7 kvintala ječma i $1-2$ kvintala prosa. Žito se nije

$9 \quad$ Prema kazivanju Mirka Prpića drveni plug sastojao se od ručica, gredelja, noža, plaza (na stranu) i crtala. U zadruzi njegove obitelji imali su i jednu drvenu branu. Sastojala se od dasaka, a odozgo su bila tri deblja drveta s klinovima. Otraga su bile pričvršćene grane, na to se stavio kamen ili je nejako dijete sjelo da pritisne zemlju.

10 O stočarstvu vidi više u prilogu Marijete Rajković u prvom svesku Monografije, str. 185-203.

11 O tome vidi više u prilogu Jasmine Jurković o tradicijskoj prehrani u ovom svesku Monografije.

12 O tradicijskom odijevanju vidi više u prilogu Aleksandre Vlatković u ovom svesku Monografije.

13 Prema Milanu Tomljanoviću neki su u selu Podbilo imali posebno zidane bajte za dimljenje i sušenje mesa. O proizvodnji suhomesnatih prerađevina vidi više u prilogu Jasmine Jurković o tradicijskoj prehrani u ovom svesku Monografije.

14 Rojeve su kupovali ili su ih tražili u šumi. Odrezali bi panjeve s pčelama, donijeli ih kući, kadili pčele (istjerali ih iz panja tako da su zapalili krpu) i istresali u košnice zvane ulišta. Ulišta su četvrtasta, od dasaka s otvorom pri dnu zvanim leto, a odozgo je poklopac koji se može podignuti. Pedesetih godina počeli su upotrebljavati moderne košnice koje su zvali šniderke. O pčelarstvu na području Krivoga Puta vidi više u prilogu Marijete Rajković o pčelarstvu u prvom svesku Monografije, str. 249-263.

15 O uzgoju povrća nema podataka za zadrugu Prpić-Grgajice. Voće nisu uzgajali. Do 1937. godine imali su samo divlju trešnju. Tek nakon diobe zadruge počeli su se baviti voćarstvom. Tomljanovići također nisu imali posebni voćnjak, već su u blizini kuće zasadili koje drvo jabuke i šljive. 
prodavalo, već se, ako je bila nerodna godina, do $60 \%$ kupovalo. Ako je urod bio bolji, manje se kupovalo, ali se uvijek moralo dokupiti jer nije bilo dovoljno dobre zemlje za uzgoj žitarica. Namjena pojedinih parcela oranica mijenjala se, tako da je, primjerice, jedne godine na komadu zemlje bilo ječmište (parcela zasijana ječmom), a druge godine krumpirište (parcela zasađena krumpirom). Zemljište se đubrilo. Đubar se vozio kolima iz štale. To je bilo grabovo, jasenovo, kljenovo ili lipovo lišće zvano šušanj, koje je bilo pod blagom. Pokupilo bi se u šumi i u jutanim vrećama nosilo pod blago u štalu. Tko nije imao kola, nosio bi đubar na magarcu ili na konjima. Đubrenje zemlje trajalo je tri dana.

Žetva je trajala 3 - 4 dana i taj su posao obavljale žene. ${ }^{16}$ Sjenokoša je trajala i više od 15 dana. ${ }^{17}$ Žito se vršilo konjima, ${ }^{18}$ zatim se vijalo na vjetru. ${ }^{19} \mathrm{U}$ vamiliji Prpić-Grgajice žito se nakon vijanja vezivalo u jutene vreće i nosilo kući, gdje se ostavljalo u badnjevima na tavanu. Za vrijeme Prvoga svjetskog rata žito se mljelo na žrvnju, ali su se manje količine mljele i na mlincu za kavu. Žrvanj nije imala svaka obitelj, pa tako ni njihova obitelj, te su morali davati ujam da im se žito samelje. Na $10 \mathrm{~kg}$ davalo se $1,5 \mathrm{~kg}$ žita na ujam, a još je k tome svatko sam sebi mlio žito. Plaćala se samo uporaba žrvnja. Iza Drugoga svjetskog rata koristili su se mlinovi na vodi kod Jurjeva pod Krmpotama. Plaćalo se za šolde ili na ujam, 2 - 3 litre za 50 kg žita. Vamilija Tomljanović-Puljiz žito je mljela u mlinu na Žrnovici kod Kljenovice, kod gazda Barbića. Za uporabu mlina plaćao se ujam, 2 - $3 \mathrm{~kg}$ na $100 \mathrm{~kg}$ žita. ${ }^{20}$

U zadruzi Tomljanović-Puljiz za trgovinu je bio zadužen gospodar kuće. Prodavao se krumpir, zelje, drva iz šume, janjci, telad, krave u Senju, a prodavali su i konje kad bi ostarjeli, u Brinju i Otočcu. ${ }^{21}$ Povremeno bi i prekupci dolazili u selo i otkupljivali. Novac od trgovine skupljao se u zajedničku blagajnu i njime se po dogovoru kupovalo sve što je bilo potrebno ukućanima. U zadruzi Prpić-Grgajice prodavalo se samo mlijeko, med i nešto vune. U objema zadrugama kupovali su se sljedeći artikli: brašno, šećer, sol, duhan, petrolej, odjeća i obuća. Obuću su kupovali kod opančara u Senju. Tomljanovići su obuću kupovali još i u Sloveniji, a teretne opanke za rad nabavljali su od gantara. U Podbilu je bio i šusteraj, pa su i tu nabavljali kožne opanke. Članovi zadruge Prpić-Grgajice su do početka Prvoga svjetskog rata sami izrađivali drvene opanke. ${ }^{22}$ Osim spomenutih artikala Prpići su kupovali još i ječam i grah, a Tomljanovići mlade svinje.

Do novca se u objema zadružnim obiteljima dolazilo zaradom stečenom izvan zadruge, a ne od poljoprivrede i stočarstva. Jedino su Puljizovi, kako je već spomenuto, prodavali neke artikle i nešto stoke, a Prpići samo mlijeko. Prehrambene potrebe zadovoljavale su se pretežito vlastitom proizvodnjom, premda

16 O žetvi nema podataka za zadrugu Puljizovih.

17 Sjenokoši je posvećen poseban prilog u prvom svesku Monografije, zbog njezine osobite važnosti u životu Krivopućana (Rajković 2008:205-220).

18 Na sredini guvna na dijelu ledine zatuče se stožen (Kosova Buljima) ili stožer (Podbilo), drvena motka, i privežu 2 - 3 konja tako da budu jedan do drugoga. Jedan ih čovjek kandžijom tjera po žitu. Milan Tomljanović Puljiz iz Tomića istaknuo je da se žito po kome konji gaze zove vršaj i da se nakon 15 - 20 minuta konji kreću u suprotnom smjeru da im se ne zavrti svist. Kad konji dobro izgaze žito, onda drugi čovjek vilama protresa žito i preokreće ga. Po tri puta se tako okretalo.

19 Žito se drvenom lopatom skrenulo kraju kad je vitar puva (M. Prpić). Kada žito odvojeno od pljeve padne na hrpu, granom zvanom šujica odvaja se preostala pljeva u slučaju da se nije sasvim odvojila na vjetru. M. Tomljanović precizirao je da je jedna žena bacala, a druga bi stavila na sebe plahtu ili neku drugu tkaninu da ne pada pliva po njoj, i odvajala ostatke pljeve granom zvanom $\check{s} u l j$.

20 Neke obitelji u selu imale su svoj ručni žrvanj. O zemljoradnji na širem području Krivoga Puta vidi više u istoimenom prilogu Marijete Rajković u prvom svesku Monografije, str. 221-247.

21 O trgovini Krivopućana unutar i izvan lokalne zajednice vidi više u prilogu Tihane Rubić u prvom svesku Monografije, str.323-352.

22 Opanci su se izrađivali na sljedeći način: izrezala bi se stopa od drveta, koža bi se privratila naopako, oko oboda bi se čavlićin za drvo pričvrstila tzv. praćica (vijenac). Vidi o tome također u prilogu o odijevanju Aleksandre Vlatković u ovom svesku Monografije. 
to nije uvijek bilo dovoljno. U objema zadrugama sve je troškove snosila zajednica, budući da je svaki član zadruge sav zarađen novac davao u zadrugu. Gospodar je određivao koliko će se trošiti i u koje svrhe. Novac je bio kod njega, a kada je bio odsutan, njegova je žena čuvala novac. Milan Tomljanović slao je novac gazdarici i ona je njime raspolagala i određivala u koje će se svrhe upotrijebiti, budući da je gazda njihove zadruge mlad umro. Dok je bio živ, čuvao je novac i o svemu vodio računa zajedno s gazdaricom.

\section{8. ŽIVOT U ZADRUZI}

Z adrugu su njezini članovi nazivali vamilija, a starješina je bio gospodar kuće. Gospodar ili gazda bio je otac, najstariji član zadruge. Mirko Prpić naglasio je kako su brojnije zadruge nazivali i velikim vamilijama, a svoju su zadrugu zvali naša vamilija. Ako je domaćin zadruge bio otac, ukućani su ga zvali još i dida ili ćaća. Ako otac nije živ, rukovođenje zadrugom preuzima najstariji brat. Ako je gospodareva žena sposobna i ona može postati gospodaricom. U zadruzi Tomljanović-Puljiz majka je postala gospodaricom jer su djeca još bila nejaka kad im je umro gospodar. Gospodarica je upravljala i određivala što će se raditi, brinula je o blagu, a sinovi su joj u tome pomagali.

U zadruzi Prpić-Grgajice zadaci gospodara bili su da pomaže u poslu, da vodi ekonomiju i plaća porez. On je raspolagao imovinom. Vodio je brigu o blagu, a kad je on umro, to je zaduženje preuzeo najstariji sin. Ostali nisu bili upućeni u taj posao jer su uglavnom bili odsutni. Gospodar nije nikoga kažnjavao, ali ako je netko bio neposlušan ili je odbijao posao, vikao je i psovao ga i dotični se morao vratiti $u$ štos, pokoriti se njegovoj volji. U načelu se malo griješilo, svatko je svoj dio posla savjesno obavljao. Ništa se nije odlučivalo bez znanja i dopuštenja gospodara.

Gazdarica je u objema zadrugama bila gazdina žena, s tom razlikom da je u zadruzi Puljizovih dosta brzo preuzela i gospodarevu ulogu zbog njegove prerane smrti. Ona je obavljala sve kućanske poslove: kuhala je i posluživala oko stola, pekla kruh, kupila jaja i vodila brigu o djeci. Gazdarica je u kući bila zvana planinka. Ako nije mogla obaviti sama sve te poslove, po potrebi bi je zamijenile kći ili nevjesta. Ostale su žene radile u polju. Rublje su žene prale po dogovoru. U zadruzi Prpića katkada je i taj posao obavljala gazdarica, a žene su uglavnom radile u polju jer muškaraca nije bilo kod kuće. Sav se posao obavljao po dogovoru. Netko bi otišao k blagu, a uvečer su sve žene pomagale svekrvi kod kuće. Najviše je posla imala mlada nevjesta jer je ona od početka trebala pokazati kakva je kućanica i kuharica. Kod Prpića je domaćinova žena postala gospodar nakon njegove smrti. Ako zna upravljati imanjem, onda ona i upravlja, a ako tome nije vična, taj dio posla preuzima najstariji brat.

Gospodar je navečer izvršio raspored poslova u polju, svakome je odredio što će raditi, a o kućnim su se poslovima žene međusobno same dogovarale. O djeci su brinuli svi zajedno, najviše stariji. Svi članovi zadruge Tomljanović-Puljiz, koja je rano ostala bez gospodara, također su se navečer dogovarali o podjeli posla za sutradan, a gazdarica je određivala što će se raditi. Nije bilo neke određene podjele posla. Žene su se također međusobno dogovarale oko svojega dijela posla. Gospodarica je određivala što će se kuhati.

Radilo se i za nadnicu, koja je bila niska, no u zadruzi Prpić-Grgajice zadrugari su sve poljodjelske poslove obavljali sami bez najamnika. ${ }^{23} \mathrm{U}$ obama selima organizirala se moba pri većim poljodjelskima poslovima kao što su košnja i žetva. Tada bi suseljani išli jedan drugome $u$ zamjenu.

U zadruzi Tomljanović-Puljiz ustajanje je ljeti bilo u 3 - 4 ure, a zimi oko 6 sati. Spavati se išlo oko 9 - 10 sati, a žene nešto kasnije. Zimi se toga nisu strogo pridržavali. Ujutro rano je bio ručak, a oko 9 sati veliki ručak, u podne užina, oko 4 - 5 sati mala užina i navečer večera. Takav je red bio ljeti kad se puno

23 Ako netko nije imao orača, zvao bi onoga tko ima konja ili vola i kola. Ako su to bili poznati, radili su im $d z ̌ a b e, ~ u$ suprotnom bi im se platilo po 100 dinara za cijeli dan. M. Prpić nije precizirao u kojem se razdoblju toliki iznos plaćao najamniku. Konji su se uprezali u ajam, a štranjge (uzde) za varigu (motku), dok su se volovi uprezali u aram (jaram). O tome vidi više u prilogu o tradicijskom prijevozu, autorice Danijele Birt u prvom svesku Monografije, str. 281-306. 
radilo, a zimi su bila samo tri glavna obroka. Hranu je majka nosila u polje na leđima u torbi od vune ili na konjima ako je polje bilo daleko. Kad se radilo na udaljenom komadu zemlje, znalo se spavati u šumi tako da se ujutro što ranije počne s poslom. Nije bilo posebno određeno gdje će tko sjediti za stolom. Ranije se jelo iz zajedničke zdjele, a kasnije svatko iz svojega pladnja.

U zadruzi Prpić-Grgajice ustajanje je ljeti bilo u 3 ure, a zimi oko 7 sati. Na spavanje se i ljeti i zimi išlo u 8 - 9 sati. Zimi su se muškarci katkada kartali, a žene su prele i plele, pa bi se u tom slučaju išlo kasnije na spavanje. Kada su ljeti bila prela, ne bi ni išli spavati jer je svatko morao od ranog jutra na posao. Prvi bi ustali gazda i gazdarica. On se morao pobrinuti za blago, a zatim bi budio ostale. Muškarci su se uključivali u poljske poslove kad su došli iz svijeta. Blagom se nisu bavili jer ga nisu znali hraniti niti s njime pravilno postupati. Za doručak zvan ručak najviše se jelo suhoga mesa, palente, kiseline, mlijeka. Za ručak zvan ǔ̌ina pripremala se tjestenina, grah, ječam, zelje i meso. Između ručka i užine postojao je i međuobrok, mala užina, koji se sastojao najčešće od sira, mlijeka ili bijele kave. Za večeru se jeo ječam, grah, tijesto, katkada i u kombinaciji. Za stolom je na čelu stola sjedio otac, a majka je posluživala. Ostali su sjedili bez posebnog redoslijeda, a djeca su se smjestila zasebno u kutu sobe. Kada je bila oskudacija, otac ili majka dijelili bi kruh i meso, a inače se svatko sam posluživao. Do 1920. godine svi su jeli iz zajedničke zemljane zdjele. Posjedali bi na malo nižu stolicu uokolo i jeli bi iz iste zdjele, a molitva je bila obvezna prije svakog jela. ${ }^{24}$ Nedjeljom i praznicima obvezno se išlo u crkvu, a u kući bi ostajala samo ona žena koja je tada bila zadužena za kuhanje.

U vrijeme postojanja zadruge, prema sjećanjima kazivača, odnosi među članovima nisu bili složni. Bez dopuštenja domaćina ništa se nije moglo učiniti, niti bilo kamo otići. Udovica je, ako se ne preuda, dobivala dio imovine svojega muža. U protivnom je dobivala samo pokretni dio imovine (stoku). U tom slučaju njezino dijete dobiva očev dio. ${ }^{25}$

Zadruga je uživala ugled u selu jer se na taj način lakše i bolje živjelo, budući da je u ovome kraju prevladavalo siromaštvo. ${ }^{26}$

\section{DIOBA ZADRUGE PRPIĆ-GRGAJICE}

$\mathrm{B}_{\mathrm{s}}^{\mathrm{i}}$ ilo je više uzroka za diobu zadruge. Nesloga između svekrve i snahe bila je glavni uzrok diobe, budući da je život u zajednici inače osiguravao lakši i bolji život: Ako je jedan pametan, a svi bedasti, lako je bilo, ali ako su više njih postali pametni, nije valjalo. ${ }^{27}$ Prema mišljenju kazivača, dijelom je uzrok bila i kriza u svijetu u vrijeme postojanja zadruga; ako su muškarci u inozemstvu loše zarađivali, nisu bili u mogućnosti slati dovoljno sredstava u zadrugu, a ona je bez tih prihoda teško mogla opstati. To je bilo poratno vrijeme i više nije bilo ekonomskih uvjeta za opstanak zadruge.

Diobu su 1947. godine izvršili otac i najstariji sin. Otac je bio za diobu, a Mirko nije jer se bojao da se samostalno neće održati. Nisu se dijelili sudskim putem, već po međusobnom dogovoru. Otac i tri brata podijelili su zemlju na četiri jednaka dijela, bez obzira na to što je samo Mirko bio oženjen. Kuća je ostala zajednička. Ocu su pripala dva dijela kuće, s tim da su s njim živjeli Joso do ženidbe, a Jure do svoje 18. godine. Mirko je sa ženom dobio sobu. Ostao je u staroj kući dok nije sagradio kuću za svoju obitelj, 2 - 3 godine nakon diobe. Godine 1961. preselio se u Senj da bi školovao djecu jer više nije bilo ni osnovne škole u selu. Joso je nakon dvije godine napustio roditeljski dom. U vrijeme ispitivanja još su imali zemlju, ali je više nitko nije obrađivao, već su za nju i dalje samo plaćali porez.

24 Molili su gazdarica i gospodar.

25 U zadruzi Prpića nije bilo domazeta. U drugim zadrugama u selu, bilo je takvih slučajeva. O tome nema podataka za zadrugu Tomljanović-Puljiz.

26 O tome više vidi u prilogu Tihane Rubić i Danijele Birt u ovom svesku Monografije.

27 Prokomentirao je Mirko Prpić. 
Mirko je dobio jednu kravu i konja, dok Joso i Jure nisu dobili ništa jer su bili s roditeljima. Ocu je pripao jedan konj i tri krave. Ostalo je oko $200 \mathrm{~kg}$ hrane. Mirko nije htio uzeti svoj dio hrane, kao ni svoj dio neobranog priroda.

Plug, kola i brana ostali su nepodijeljeni. Svi su ih i nakon diobe koristili po potrebi i dogovoru.

\section{DIOBA ZADRUGE TOMLJANOVIĆ-PULJIZ}

$\mathrm{D}$ o diobe zadruge došlo je zbog toga što je broj članova vamilije narastao, a svatko je želio biti svoj gospodar. Dioba je izvršena 1936. godine. Nije ih podijelila majka, već su se braća međusobno dogovorila o diobi. Zemlju su podijelili na tri jednaka dijela, na taj način da su svaki komad zemlje dijelili na tri dijela. Jednu parcelu dijeli jedan brat, drugu drugi i tako redom dok se zemlja nije sasvim podijelila. Manje parcele nisu dijelili, već su ih naizmjenično koristili, svake godine drugi brat. Nisu se podijelili putem suda, već je to bila tajna dioba koja je zakonski provedena tek nakon Drugoga svjetskog rata. ${ }^{28}$

Blago su dijelili na jednake dijelove po lozama. I blago su dijelili po izboru, ali tako da je svaki brat u tome ravnopravno sudjelovao.

Kuća je ostala najmlađem bratu Frani. Štala je pripala najstarijem bratu Grgi, koji si je nad štalom nadogradio kuću. Majka je po svom izboru ostala s Grgom. Zbog toga je Grgo dobio komad zemlje više i kravu, kojima je raspolagao do majčine smrti. Milan je sebi izgradio kuću pored štale preuređene u kuću (Sl. 2).

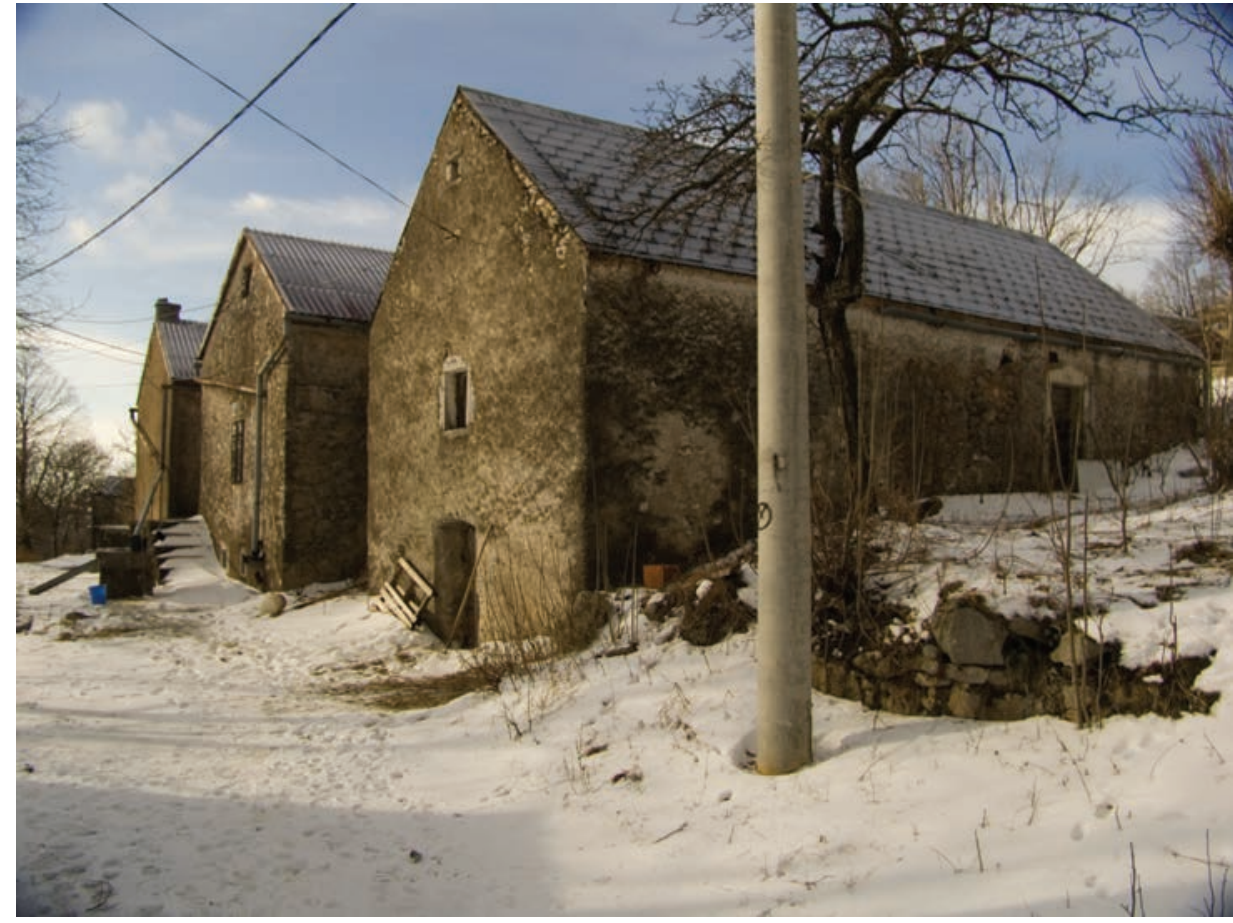

Slika 2: U prvom planu je novoizgradena kuía Milana Tomljanovića Puljiza nakon diobe zadruge. Pored kuće su u pozadini ostale dvije kuće koje su pripale nakon diobe Grgi (kuća izgradena nad štalom) i Frani (stara zadružna kuía). Snimio Augustin Perić, siječanj 2009.

Obrani i neobrani prirod podijeljen je na približno jednake dijelove. Nepodijeljeni su ostali plug i kola kojima su se sva tri brata po potrebi i dogovoru služila.

28 Usporedi s dijelom teksta Tihane Rubić i Danijele Birt u ovom svesku Monografije, u kojemu se govori o tradiciji unutarobiteljskih, dogovornih diobi i izbjegavanju sudski registriranih dioba. 


\section{ZAKLJUČNA RAZMATRANJA}

$\mathrm{P}$ remda nepotpuni, podaci prikupljeni terenskim istraživanjem u 1981. godini o dvije zadružne obitelji na Krivome Putu veoma su dragocjeni, budući da je život primorskih Bunjevaca u obiteljskim zadrugama potpuna nepoznanica. Zanimljive su pojedinosti o načinu diobe dviju prikazanih zadruga. Obje su se zadruge podijelile interno, po dogovoru, ne i sudski. Zadruga Tomljanović-Puljiz se i formalno podijelila tek kad je to postalo obvezno po zakonu. I nakon diobe članovi bivše zadruge Prpić-Grgajice ostali su živjeti 2 - 3 godine na istom prostoru. Osim toga, po potrebi su zajednički upotrebljavali nekadašnji zadružni ratarski pribor, a uz to je svaka odijeljena obitelj Tomljanovićevih imala pravo naizmjenično obrađivati manje nepodijeljene parcele zemlje. Takve okolnosti diobe ovih dviju zadruga pokazuju elemente postupne diobe zadruga. Do diobe dolazi, između ostaloga, i zbog težnje pojedinih članova zadruge ka samostalnosti, izražene u stjecanju vlastitih prihoda (čega je dijelom bilo i u vrijeme postojanja zadruga), te zbog novonastalih ekonomskih prilika, no istodobno, može se zapaziti određeni stupanj zajedništva i nakon diobe. Prpići su i dalje živjeli 2 - 3 godine u zadružnoj kući. Osim toga, njihova zadruga i u vrijeme njezina postojanja nije zadovoljavala sve kriterije koji jednu obitelj čine zadružnom, ali i u takvom „krnjem“ obliku njezini zadnji potomci smatrali su je zadrugom. Članovi bivše zadruge Tomljanović-Puljiz nastavili su živjeti na istom prostoru: jedan brat pretvorio je štalu u stambeni prostor, drugi je pored nje izgradio novu kuću, a zadružna kuća pripala je trećem bratu. Zasad su to jedini podaci o diobi zadruga na ovom području i samim time zapravo nema dovoljno pokazatelja o tendenciji postupne diobe zadruga kod primorskih Bunjevaca. Ipak se i na tako malom uzorku istraživanja mogu zapaziti određeni pokazatelji postupne diobe kroz specifične prijelazne oblike iz zadružne u inokosnu obitelj. Ti su pokazatelji zanimljivi i zbog toga što su takve tendencije uočene i u nekim jugoistočnim dinarskim krajevima te kod bačkih Bunjevaca, osobito u južnoj Mađarskoj (Černelić 1990:318, 320; ibid. 2006: 145-149; 151-152).

Postupni prijelazni oblik iz zadružnog u inokosni sustav obiteljskog života, karakterističan je i za zadrugu Rukavina-Jauci u Smiljanskom Polju u Lici, premda je nastupio znatno kasnije nego što je to bio slučaj na drugim prostorima (ibid. 1999a:310; ibid. 2006:29-39). Prema oskudnim podacima o zadrugama s područja Like, prave diobe zadruga u njihovoj završnoj fazi postojanja nije ni bilo jer su se one većinom raspadale zbog loših ekonomskih prilika, kao i učestalih odlazaka stanovništva Like u svijet, u potrazi za zaradom (Hećimović-Seselja 1960:15; Černelić EZ FFZ 133). Zanimljiv je i primjer zadruge Došena iz Brušana kod Gospića, koja je bila pred diobom još 1929. godine, ali je dioba odgođena, pa je zadruga smrću zadnjega gospodara prestala postojati, a preživjeli brat je preuzeo brigu o majci. Druge zadruge u selu su se dijelile, ali je, prema mišljenju kazivača Stipana Došena, jedini uzrok tome bila nesloga žena; one su na taj čin nagovorile svoje muževe koji se svojevoljno ne bi odlučili na taj korak (Černelić EZ FFZ 134).

Premda nedostatni, podaci o diobi pojedinih zadruga u Primorju i Lici pokazuju zanimljivu tendenciju opstojnosti određenih elemenata zadružnog načina života i nakon što su zadruge formalno prestale postojati. Za određenije zaključke o pojavi postupne diobe ili prirodnog odumiranja zadružnog načina života trebalo bi obaviti daljnja arhivska istraživanja obiteljskih zadruga i oblika njihove diobe na prostoru Primorja i Like naseljenom Bunjevcima. Istovremeno, etnološka (kvalitativna, terenska) istraživanja na Krivome Putu pokazala su da je podrobnije istraživanje ove teme danas gotovo neizvodivo.

\section{LITERATURA I IZVORI:}

ČERNELIĆ, Milana (1981): Zadruge u Trnovcu. Etnološki zavod Filozofskog fakulteta u Zagrebu (EZ FFZ), br. 133.

ČERNELIĆ, Milana (1981): Zadruga Došen, Brušane. Etnološki zavod Filozofskog fakulteta u Zagrebu, (EZ FFZ), br. 134. 
ČERNELIĆ, Milana (1990): O tragovima zadruge kod Bunjevaca u južnoj Mađarskoj. Migracijske teme, 6(3):311-323, Zagreb.

ČERNELIĆ, Milana (1999): Zadruga Rukavina -Jauci iz Smiljanskog polja kod Gospića. Senjski zbornik, 26:297-312, Senj.

ČERNELIĆ, Milana (2000): Dvije zadružne obitelji na području Krivoga puta. Senjski zbornik, 27:199216, Senj.

GAVAZZI, Milovan (1978): Sudbina obiteljskih zadruga jugoistočne Europe. U: Vrela i sudbine narodnih tradicija, Sveučilišna naklada Liber, Zagreb, 80-93.

HEĆIMOVIĆ-SESELJA, Mara (1960): Zadruga Ivčević-Hećimović, selo Ivčević Kosa - kotar Gospić. U: Seljačke obiteljske zadruge 1, Publikacije Etnološkog zavoda Filozofskog fakulteta Sevučilišsta u Zagrebu, 3, Zagreb, 5-17. 